\title{
Research of Confucianism Education Method in Chinese College Students' Ideological and Political Education
}

\author{
Long Guo \\ Organization Department, Southwest Petroleum University, Chengdu, China \\ Email:guolong2016@163.com
}

Received 9 March 2016; accepted 22 May 2016; published 25 May 2016

Copyright (C) 2016 by author and Scientific Research Publishing Inc.

This work is licensed under the Creative Commons Attribution International License (CC BY).

http://creativecommons.org/licenses/by/4.0/

(c) (†) Open Access

\begin{abstract}
With the rapid development of Chinese economy and society, the ideological condition of college students continuously presents new characteristics, and also brings challenge to ideological and political education work effectiveness. Because of the upsurge of "Chinese culture" in recent years, some scholars have begun to study the idea of Confucian psychological education. How to integrate Confucian psychological education into the ideological and political education of college students will become a new hot spot and the difficulty. Study of Confucian thoughts on psychological education, using Confucian thoughts on psychological education and methods to strengthen college students' psychological quality, to strengthen the cultivation of students' psychological quality, and to further enhance the system and effectiveness of the ideological and political education of college students, is not only the requirement of students' healthy growth, and social expectations of university ideological and political education work.
\end{abstract}

\section{Keywords}

College Students, Party Construction, Southwest Petroleum University, New Methods

\section{Introduction}

The Chinese nation has a long history and excellent cultural tradition. Excellent traditional culture can not only enhance the national pride and self-confidence, but also can enhance the ideological realm of the educated (Brown, Odom, McConnell, \& Rathel, 2008). Confucian thought of psychological education in the development of thousands of years, especially in the development of the Asian countries in recent years shows the value of its existence. The party's understanding of the law of cultural construction is becoming more and more comprehensive, and more and more profound (Brown, Odom, \& McConnell, 2008). Therefore, strengthening and improv- 
ing the ideological and political education of college students, raise their ideological and political quality, in order to ensure that the cause of socialism with Chinese characteristics and flourishing has qualified successors. As the motherland and the people are given the task of college students, their ideological and spiritual life is directly related to the rejuvenation of the nation and the future development of the country. Therefore, the Party Central Committee has been working as an important strategic task for the ideological and political education of college students, and has been continuously strengthened and improved for the guidance of ideological and political education for college students. With the deepening of ideological and political education of college students, the effect of education will be concerned by all aspects of the society. In this background, the integration of the study of Confucian thoughts on psychological education and ideological and political education of college students, helps to compensate for the lack of ideological and political education work, helps to promote innovation and development of the college students' ideological and political education work, and is very important and necessary (Brownell, 2002).

\section{An Overview of Confucian Educational Thoughts}

The Confucian mentality education thought is the treasure of Chinese traditional culture, it is part of the splendid cultural heritage of China, and it is an important crystallization of human wisdom. It attaches importance to the cultivation of people's psychological quality, focusing on maintaining people's health, improve people's ability to be frustrated, establish a person's self-confidence, how to get along with others. The psychological education is long-standing and well-established, including the importance of "the golden mean" psychological education, emphasizes the "harmonious" psychological education and pay attention to "tough" psychological education. The main features of his thinking is to people-centred, advocating harmony, advocating morality. The outstanding Confucian Thoughts on psychological education into the ideological and political education of college students is need to cope with the negative effects of the market economy, is to enhance the effectiveness of Ideological and political education, is to adapt to the needs of the situation of development of higher education (Colvin, Kameenui, \& Sugai, 1993).

\section{The Problems of College Students' Ideological Education in China}

The mainstream of the ideological and political situation is positive, healthy and upward, but also there are some problems in different degrees, its performance in the following aspects:

\subsection{Political Consciousness}

Contemporary college students' enthusiasm is not high to politics activity, a survey results in only $16.67 \%$ of the students like to focus on the political, the other for the political apathy. This is compared with the strong political participation consciousness of university students in the end of the 1970s and 1980s, the generation of College Students' participation in political activities is poor. The main reason is the outlook on life, the values, the employment problem and the social environment. The phenomenon of political apathy of contemporary university students is of great negative impact on the development of democratic politics construction and social stability and the healthy growth of college students. It is not conducive to the overall development of college students.

\subsection{Moral Character}

Moral quality has an important role in people's physical and mental development, with good moral character, can make college students to establish a correct outlook on life and values. But the moral qualities of contemporary college students have serious problems. In polite to treat friendship, honesty, and the feelings of love and filial to parents and so on various aspects all problems, even some people addicted to the virtual network world. As in higher education of college students, itself should have the ability to judge and losses as well as the fine traditional virtues. Everyone should first learn to behave, to learn to do things better. The moral can't be lost at any time, or you will lose the direction and go astray.

\subsection{Value Orientation}

The diversification of value orientation has always been accompanied by the diversification of interests' relation. 
The diversification of university life conditions must be revealed in the specific, individual ideological and psychological state. According to the current situation of college students, the complicated ideological concepts of college students are reflected in the diversification of beliefs, beliefs and ideals. Some students blindly advocate hedonism, money worship, compare the heart is strong, the lack of dedication and so on. These undesirable phenomena mislead the value orientation of college students. Generally speaking, the diversification of value orientation will inevitably make the development trend of contemporary college students' political, moral and psychological.

\subsection{Mental Health}

The healthy psychological quality is the necessary condition for the smooth development of college students, and the inner guarantee of the success of the enterprise. However, in the social and economic change, the conflict between Chinese and Western culture, all kinds of thoughts collide, all kinds of contradictory phenomena appear constantly, resulting in a variety of psychological conflict and psychological barrier. Such as interpersonal relationships in the locked mentality, career choice of anxiety, love in the personality of fission and a variety of mental illness and other issues.

\section{The Method of Applying Confucian Educational Thought to the Ideological Education of College Students}

\subsection{Give Full Play to the School Teachers' Role Setting of Confucian Education Curriculum}

The development of school teaching resources, the most important is to enrich the content of teaching and education, the most effective is to set up related courses. First of all, the school to organize the teacher carefully developed a unique teaching materials, carefully planned with the Confucian ideological characteristics of the course, hired famous teachers to set up a class, to inspire students to understand the content of Confucian psychological education. Secondly, based on the course to teach students the methods of health education of Confucianism, the formation of inside and outside class, education and counseling, counseling and self-help system combination. At present, the public subjects in Colleges and universities are narrow, and the course of liberal arts is relatively small. Schools should intensify reform and innovation, not only to open some of the students to find a job, to learn technology, to help test the curriculum, but also should pay attention to the opening of the Confucian idea of psychological education courses.

\subsection{The Effective Use of Educational Resources, Propagandize Excellent Confucian Ideological Education}

School education resource is a resource that contains a certain value of education, can promote the smooth development of school education activities. First of all, the use of school cultural resources. The school cultural resources are the core and soul of the school's internal resources, which are guided by an invisible force, bound, inspire and regulate the thought and behavior of teachers and students. Including spiritual and cultural resources, the system of cultural resources, environmental and cultural resources, etc.. To make use of the resources of school culture, realize the organic combination of Ideological and political education of college students and the ideological education of Confucianism. On the one hand, the school leader, the school each department, each link to coordination and create a good campus environment for the school. To establish a newspaper column, blackboard, culture wall, to focus on propaganda psychological education of Confucianism outstanding thought, the school will regularly organize cultural activities, speech contests, student associations to increase the construction of the academic community, promote innovation of the Confucian culture research, Confucius Research, cultural tradition of research community. Secondly, the use of school human resources. Human resource is the most active factor in all resources. First, strict requirements to teachers, optimize the structure of teachers, as far as possible to provide training for teachers to learn the opportunity. Network ideological and political education workers should through continuous learning, can make equal communication with students, to be able to use network this platform when faced with different psychological problems of students give full play to the advantages of Confucian psychological education thoughts. Also establish student QQ group, microblog, letters and other modern network means, every day on the micro blog for the students to tell a little story about the Confucian educational ideas, making college students learning to enrich and interesting. 


\subsection{The Use of Confucian Education Ideological Education of Students}

The purpose of school education is to cultivate students become talents, only closely around can enhance the effect of education. To effectively combine the Confucian thoughts of psychological education, from the ideological and political education, must be closely around college students become talents. First of all, the school should form a cohesive spirit and learning atmosphere, Positive spirit can inspire the students' healthy growth, School departments, professional to form a good atmosphere, School organize to carry out the courtyard atmosphere, class atmosphere and appraisal, winner to give the material and spiritual incentive, incentive educators and students work together. On the other hand, there must be strict discipline and punishment system should be clear. With system constraints, the principles of students, to ensure timely, fair and just deal with the problem. In this way can we form a good atmosphere, to guarantee the Confucian thought of psychological education has a healthy and stable positive environment. Secondly, the teacher should be equal to the teacher and student relationship, so as to better understand the students, close to the students. Finally, relying on parents to help complete the task of students' education (Crozier \& Tincani, 2005).

\subsection{To Strengthen Students' Counselors' Education Improve the Excellent Ideas of Confucian}

To strengthen and improve ideological and political education work is a systematic project, need to transfer the power of many aspects, such as school and society (Docherty, 2012). But in all the relevant factors, the student counselors are undoubtedly one of the key factors, their excellent ideological and political education of the Confucian school will have a vital impact on the ideological and political education (Gamage, Suwanabroma, Ueyama, Hada, \& Sekikawa, 2008). From the ideals and beliefs to the health examination, specific to the development of Party members recommended, appraised to choose, students and counselors all without exception occurred in close contact. In view of this, to strengthen the Confucian education thoughts of student counselor is an important part in education (DeLuzio \& Girolametto, 2011).

\section{Conclusion}

With the rapid development of Chinese economy and society, the ideological condition of college students continuously presents new characteristics, and also brings challenge to ideological and political education work effectiveness (Liu, Li, \& Yang, 2012). In the face of these problems, we need to constantly innovate the way of ideological and political education of college students (Power, 2015). How to correctly treat Chinese traditional culture, to learn the essence of good ideas to better service for the development of college students' ideological and political education is important. Because of the upsurge of "Chinese culture" in recent years, some scholars have begun to study the idea of Confucian psychological education. How to integrate Confucian psychological education into the ideological and political education of college students will become a new hot spot and the difficulty.

\section{References}

Brown, W. B., Odom, S. L., McConnell, S. R., \& Rathel, J. M. (2008). Peer Interactions for Preschool Children with Developmental Difficulties. In W. B. Brown, S. L. Odom, \& S. R. McConnell (Eds.), Social Competence of Young Children with Disabilities: Risk, Disability, and Intervention (pp. 141-164). Baltimore: Paul H. Brookes.

Brown, W., Odom, S. L., \& McConnell, S. R. (2008). Social Competence of Young Children: Risk, Disability, and Intervention (pp. 141-163). Baltimore: Brookes.

Brownell, M. D. (2002). Musically Adapted Social Stories to Modify Behaviors in Students with Autism: Four Case Studies. Journal of Music Therapy, 39, 117-144. http://dx.doi.org/10.1093/jmt/39.2.117

Colvin, G., Kameenui, E. J., \& Sugai, G. (1993). Reconceptualizing Behavior Management and School-Wide Discipline in General Education. Education and Treatment of Children, 16, 361-381.

Crozier, S., \& Tincani, M. J. (2005). Using a Modified Social Story to Decrease Disruptive Behavior of a Child with Autism. Focus on Autism and Other Developmental Disabilities, 20, 150-157. http://dx.doi.org/10.1177/10883576050200030301

DeLuzio, J., \& Girolametto, L. (2011). Peer Interactions of Preschool Children with and without Hearing Loss. Journal of Speech, Language, and Hearing Research, 54, 1197-1210. http://dx.doi.org/10.1044/1092-4388(2010/10-0099)

Docherty, T. (2012). Research by Numbers. Index on Censorship, 41, 674. http://dx.doi.org/10.1177/0306422012456132 
Gamage, D. T., Suwanabroma, J., Ueyama, T., Hada, S., \& Sekikawa, E. (2008). The Impact of Quality Assurance Measures on Student Services at the Japanese and Thai Private Universities. Quality Assurance in Education, 16, 181-198. http://dx.doi.org/10.1108/09684880810868457

Liu, K., Li, Y., \& Yang, X. (2012). The Reform and Enlightenment of Australian Higher Education Quality Assurance in New Period. Shanghai Journal of Educational Evaluation.

Power, C. (2015). Higher Education: The Engine of Development. In: The Power of Education. Singapore: Springer. http://dx.doi.org/10.1007/978-981-287-221-0_10 